\title{
The Team-Based Learning (TBL) methodology articulated with the TBL Active platform in Accounting learning in the technical course in Administration
}

La metodología Team-Based Learning (TBL) articulada con la plataforma TBL Active en aprendizaje Contable en el curso técnico en Administración

A metodologia Team-Based Learning (TBL) articulada à plataforma $T B L$ Active na aprendizagem de Contabilidade no curso técnico em Administração

\section{Volumen 21, Número 3 \\ Setiembre - Diciembre}

pp. 1-29

\section{Sandra Cristina Pelegrini Giacomelli Raquel Rosan Christino Gitahy Adriana Aparecida de Lima Terçariol}

\section{Citar este documento según modelo APA}

Giacomelli, Sandra Cristina Pelegrini., Gitahy, Raquel Rosan Christino. e Terçariol, Adriana Aparecida de Lima. (2021). The Team-Based Learning (TBL) methodology articulated with the TBL Active platform in Accounting learning in the technical course in Administration. Revista Actualidades Investigativas en Educación, 21(3), 1-29. Doi. 10.15517/aie.v21i3.46396 


\title{
The Team-Based Learning (TBL) methodology articulated with the TBL Active platform in Accounting learning in the technical course in Administration
}

\author{
La metodología Team-Based Learning (TBL) articulada con la plataforma TBL Active en \\ aprendizaje Contable en el curso técnico en Administración \\ A metodologia Team-Based Learning (TBL) articulada à plataforma TBL Active na \\ aprendizagem de Contabilidade no curso técnico em Administração
}

\section{Sandra Cristina Pelegrini Giacomelli ${ }^{1}$ Raquel Rosan Christino Gitahy ${ }^{2}$ Adriana Aparecida de Lima Terçario/ ${ }^{3}$}

\begin{abstract}
The current article constitutes in an excerpt from the Mater's Degree research entitled as "The use of the Team-Based Learning (TBL) Methodology allied to technology: Perceptions over the learning of basic accounting in the Technical Course in Administration". The question that guided the development of this Master's research was: can the Team-Based Learning (TBL) active methodology allied to digital technology provide collective learning of basic accounting concepts in the Technical Course in Administration? Based on this inquiry, the main purpose of the study presented in this article was to evaluate the contributions of the use of the TBL methodology, combined with the free platform TBL Active, which was created to assist in the application of this active methodology, in learning the basic concepts of Accounting in the technical course in Administration. The approach adopted was the qualiquantitative one since this study combined qualitative and quantitative methods in an intervention research. The development of this research took place in a public school, in the technical course in Administration, placed in the countryside of São Paulo/Brazil. Therefore, the participants were set as a class of 34 students. The observation and application of surveys were used as data collection tools. The main results showed the occurrence of collective learning of Accounting. Other than that, when comparing the individual answers to the collective answers, it showed significative successes. The active participation and the significative learning of the given content were achieved by means of the Team-Based Learning Methodology.
\end{abstract}

Key words: methodology, accounting, technical education, activity learning, team-based learning.

\footnotetext{
${ }^{1}$ Universidade do Oeste Paulista, Presidente Prudente-SP, Brasil. Dirección electrónica: sandrapelegrinii@hotmail.com Orcid: https://orcid.org/0000-0001-5923-781X

2 Universidade do Oeste Paulista, Presidente Prudente-SP, Brasil. Universidade Estadual do Mato Grosso do Sul, Paranaíba-MS, Brasil. Dirección electrónica:
} raquelgitahy.rg@gmail.com Orcid: https://orcid.org/0000-0002-5387-9536

3 Universidade Nove de Julho, São Paulo, Brasil. Dirección electrónica: atercariol@gmail.com Orcid: https://orcid.org/0000-0002-5824-2294

Artículo recibido: 25 de marzo, 2021 Enviado a corrección: 10 de junio, 2021

Aprobado: 16 de agosto, 2021 
Resumen: Este artículo es un extracto de la investigación de la Maestría titulada "El uso de la Metodología de Aprendizaje Basado en Equipos (TBL) combinado con la Tecnología: Percepciones sobre el Aprendizaje Contable Básico en el Curso Técnico de Administración". La pregunta que orientó el desarrollo de la investigación de este Máster fue: ¿puede la metodología activa de Aprendizaje Basado en Equipos (TBL), combinada con la tecnología digital, proporcionar un aprendizaje colaborativo de conceptos básicos de contabilidad en el curso técnico de Administración? Con base en esta investigación, el propósito principal del estudio presentado en este artículo fue evaluar las contribuciones del uso de la metodología TBL, combinada con la plataforma gratuita TBL Active, que fue creada para ayudar en la aplicación de esta metodología activa, en aprender los conceptos básicos de Contabilidad en el curso técnico de Administración. El enfoque adoptado fue el mixto, ya que este estudio combinó métodos cualitativos y cuantitativos en una investigación de intervención. El contexto en el que se desarrolló esta investigación fue un curso técnico en Administración, impartido en una escuela pública ubicada en una pequeña ciudad en el interior de São Paulo/ Brasil. Por tanto, se definió como participantes una clase de 34 estudiantes. Como instrumentos de recolección de datos se utilizaron la observación y la aplicación de cuestionarios. Los principales resultados demostraron la ocurrencia de un aprendizaje colaborativo de contabilidad. Además, dejaron en claro que había respuestas correctas al comparar tanto las respuestas individuales como las efectuadas en equipo. Se logró la participación activa y el aprendizaje significativo del contenido con la aplicación de la metodología Team Based Learning.

Palabras clave: metodología, contabilidad, educación técnica, aprendizaje active, aprendizaje en equipo.

Resumo: O presente artigo constitui-se um recorte da pesquisa de Mestrado intitulada "O Uso da Metodologia Team-Based Learning (TBL) aliada à Tecnologia: Percepções sobre a Aprendizagem de Contabilidade Básica no Curso Técnico em Administração". A questão que norteou o desenvolvimento desta investigação de Mestrado foi: a metodologia ativa Team-Based Learning (TBL) aliada à tecnologia digital pode proporcionar uma aprendizagem colaborativa de conceitos básicos de Contabilidade no curso técnico em Administração? A partir dessa indagação, definiu-se como principal finalidade para o estudo apresentado neste artigo avaliar as contribuições da utilização da metodologia TBL, aliada à plataforma gratuita TBL Active, que foi criada para auxiliar na aplicação dessa metodologia ativa, na aprendizagem de conceitos básicos de Contabilidade no curso técnico em Administração. A abordagem adotada foi a quali-quantitativa, uma vez que este estudo combinou métodos qualitativos e quantitativos em uma pesquisa intervenção. O contexto no qual esta pesquisa se desenvolveu foi um curso técnico em Administração, ofertado em uma escola pública situada em uma cidade de pequeno porte, no interior de São Paulo/Brasil. Sendo assim, definiu-se como participantes uma turma de 34 estudantes. Como instrumentos de coleta de dados, utilizou-se a observação e a aplicação de questionários. Os principais resultados demonstraram a ocorrência de uma aprendizagem colaborativa da Contabilidade. Além disso, explicitaram de forma significativa que houve acertos, quando comparadas as respostas individuais e em equipe. A participação ativa e a aprendizagem significativa do conteúdo foram alcançadas com a aplicação da metodologia Aprendizagem Baseada em Equipes.

Palavras-chave: metodologia, contabilidade, ensino técnico, aprendizagem ativa, aprendizagem baseada em equipes. 


\section{Introduction}

The education must be thought in an engaging way, allowing the student to interact, think autonomously, whether in the classroom or beyond, by itself or in a group, connected to the virtual world or performing practical experiments.

In order to make a student capable of competences such as autonomy, collaboration, reflection and critical thinking, active learning methodologies are usually utilized.

Active methodologies have the potential to arouse curiosity, as the students insert themselves into theorization and bring new elements not yet considered in class or from the own teacher's perspective. When the student's contributions are considered and analyzed, making them valuable, feelings of engaging, skills perception and belonging are stimulated, such as persistence in studies, among others (Berbel, 2011, p. 28)

This research made use of the active learning methodology applied to a Technical Course in Administration. The academic formation in Administration, whether as a technical course or as a graduation, may be highlighted by its wide variety of options for the future professionals to act, offering opportunities at the public sector or at various segments of the private sector, which highlights the importance of the administrator.

The labor market expects the professional administrators not only to have an innovative, creative and entrepreneur profile, but also that they know how to relate to people and deal with them, manage and take decisions. According to Chiavenato (2014, p. 78), "nowadays, the administrator is not only a mere business and people's activities supervisor". The same profile is expected from the future technical in the administration, who needs to be dynamic and entrepreneur, focused on managing a business and skilled to comprehend and analyze accounting reports to extract information and write management reports. One of the closest sectors to the administrator is the Accounting, which is responsible for recording actions and facts regarding accounting, in which the elaboration of the reports about economic and equity life of the company are going to be based on, such as the ones made to extract management information, which is vital for decision making.

This research took place in the context of the technical teaching regarding the technical course in Administration in a public school, using the active learning methodology Team-Based Learning (TBL), which provides the student the opportunity to participate in activities that seek its development, using technology as a mediator tool.

In this way, this research was guided by the following question: can the active methodology TBL along with the technology provide a collaborative learning of basic 
Accounting concepts in the technical course in Administration? From this issue, the main goal was defined: to evaluate the contributions of using the active methodology Team-Based Learning (TBL), along with the app TBL Active ${ }^{4}$, with the intention of learning basic Accounting concepts in the technical course in Administration. Thus, an interactive learning was sought, aiming that the students of the technical course in Administration focusing basic Accounting concepts build their own knowledge in an active way.

Besides the introduction, this article presents other four sections. In the first one, the theoretical reference is approached and unfolds into the following subsections: Active Methodologies and Learning in the Digital Era; Team-Based Learning Methodology; Technology for the applying of the TBL active methodology: the app TBL Active. Following, the methodology that includes the research approach; the units of analysis; the data collection instruments is presented. Then, in the results and discussion section, the intervention is described and the data triangulation with the theory is made. In the end, the conclusions, the references and the appendix are made explicit.

\section{Theoretical reference}

\subsection{Active Methodologies and Learning in the Digital Era}

The methodology points at which way the teacher intends to follow in the teaching and learning process in order that the student can build its own knowledge. For a long time, the most used methodology involved expository classes, in which the teacher shared with the students knowledge built through the times. According to Dewey (1979, p. 4), in traditional school, "the subject or content of education consists in bodies of information and abilities which have been elaborated in the past; the main task of the school, therefore, is to transmit those to the next generation". Also, about the traditional school, the author adds that, this model worries about acquiring habits that follow social rules and disciplinary orders, following a static model of teaching, with the purpose of preparing students for the future, making them receptive and obedient. In this model, the teacher connects the students to the knowledge.

Opposing the traditional, Dewey proposes a new education model that goes through experience, but stating that "the quality of any experience has two aspects: the immediate one, which can be pleasant or unpleasant, and the mediate, which refers to its influence over future experiences." (Dewey, 1979, p. 16). To reinforce the importance of an education that promotes

\footnotetext{
4 The app can be accessed at the website: https://www.tblactive.com.br/
} 
learning through experiences, he highlights that it is not about previous experiences that already existed at the empiricism, because not all of them are educational, it is about the productive experiences, that result in the student being interested in learning and deepening its knowledge, preserving the interaction with the environment and the spontaneity.

In this way, seeking the active participation of the student in the process of building its own knowledge, the active methodologies promote involvement from the students during the whole process of learning. Berbel (2011, p. 28) states that "the active methodologies have the potential to awaken curiosity, as the students are inserted into the theorization and bring new elements not yet considered in the classes or from the own perspective of the teacher". As school is inserted in society, as they both evolve together, some changes are happening to fulfill the needs of the current students. New ways of teaching propose an active participation from the students in their learning process. For Crescer Institute, the active methodologies:

Have as main characteristics, in a general way, making the students search for solutions to real world issues, get their hands dirty, be protagonists of their own learning process, research, work as a team and, with determined time for the task, use digital technologies and self-evaluate themselves. (Instituto Crescer, 2018, p. 11)

From this perspective, the teacher is no longer the knowledge holder, it abandons the class spotlight to become the mediator during the process. According to Berbel (2011, p. 29), "the teacher acts as an advisor or facilitator in order that the students research, reflect and decide, for themselves, what to do in order to accomplish the established goals".

The Guide Growing in Network: Active Methodologies (Instituto Crescer, 2018, p. 17) brings us a reflection based on two important authors about the participation of the student in the learning process:

The studies of John Dewey (1959), which were guided by the learning by doing model applied to experiences with an educational potential, converge with the ideas of Paulo Freire (1996), in which the learning experiences should awaken the curiosity of the student, allowing it to, when thinking concretely, become aware of reality, being able to question it and, thus, the knowledge building becomes able to actually transform the student. 
The process of learning from the use of active methodologies must happen upon the resolution of real issues or situations, into which the students are going to apply their previous knowledge, building new possibilities.

Some models that provided a favorable environment for the active participation of the student may also be highlighted, such as hybrid teaching (or blended-learning); the flipped classroom; the team-based learning; the problem-based learning; the peer instruction; the gamification; among others. The blended-learning model has been used as a methodology that merges the classroom teaching with activities at certain moments, using distance technology resources, in which the students are able to choose the time and the group in which the activities are going to be carried out (Valente, 2014). In order to present a broader definition, we are going to use Staker and Horn (apud Valente, 2014, p. 84):

They define blended learning as a formal education program, that mixes moments of online teaching with classroom teaching moments, in which the students are able to interact with each other and with the teacher.

One of the possibilities of the blended learning is the flipped classroom, which consists of a strategy that allows the teacher to plan classes, provide contents through digital platforms in order that the student has a previous contact with the content to be taught. According to Valente $(2014$, p. 82):

The integration of the TDIC in the classroom activities has been providing what is known as blended learning, which contains a modality named flipped classroom, that is being implemented not only into the Basic Education, but also into the Higher Education.

As a sequence of this methodology, an experiment is done through the same platform, producing results thar are going to be guiding the teacher towards the best way of performing activities in the classroom, exploring the contents and promoting experience exchanges. Valente (2014, p. 83) states that "The combination of the on-line experience with the classroom experience can be very valuable and benefit the students' learning under every aspect".

The hybrid teaching through the flipped classroom model may also ground the application of other strategies, such as the Team-Based Learning methodology, which seeks to develop the learning experience through an education that promotes critical thinking and an active participation of the students. As the process and its stages involve the methodology studied by this research, they are going to be approached in the next section. 
Thus, the active methodologies provide to the students an option to experience and participate in activities that contribute actively to the knowledge building, either through concrete practice or through observation and reflexive interiorization, either in individual activities or in a group.

\subsection{Team-Based Learning Methodology}

Team-Based Learning Methodology has been developed by Larry Michaelsen at the Oklahoma University, in the United States, by the end of the 1970's decade, in a class of Administration. The strategy came from the need of teaching to a crowded classroom, in an attempt to avoid long and theoretical classes, as Krug et al. (2016, p. 603) presents:

This challenge turned into an opportunity to Larry K. Michaelsen, who, by the end of the 1970's decade, was used to teach to small groups and had to teach a 120-student classroom at the Oklahoma University Business School. In order to avoid long theoretical classes, the teacher proposed multiple sequenced activities. Fortunately, at the end of the semester, he noticed that most of the students took responsibility not only for their own learning, but also for their colleagues' learning. The big size of the group was also a factor that helped students to consider the environment as conducive for learning. Michaelsen named this methodology as Team-Based Learning (TBL) and released it into the academia.

This methodology consists, initially, of the students doing a previous study of the contents brought by the teacher. In the classroom, the teacher applies an individual test, in order to identify what the student understood. Then, the classroom is divided in groups containing five to seven members, the groups are formed in a miscellaneous way, avoiding that the students pick their groups based on affinity. The teacher proceeds to apply the same test once again, but this time, it must be solved in a group. After the results of the test, which gives immediate feedback, the teacher retakes the content, approaching, mainly, the parts with which the students struggled the most. This practice seeks to clarify possible doubts that still remain, making possible that the students appeal whenever a student disagrees with the exposures brought by the teacher.

Then, the time to deepen knowledge comes up, the students should seek, in a group, solutions to day-to-day issues. This is the main topic of the purpose, the time to discuss divergent ideas, to interpret the case, to reason and to build a result that represents everyone's 
understanding. The result is evaluated by the teacher, who is responsible for complementing and enriching it, showing various possibilities to the students and intervening when needed. The following Figure 1 contains a systematic representation of this methodology.

Figure 1.

Structure of the Team-Based Learning Methodology.

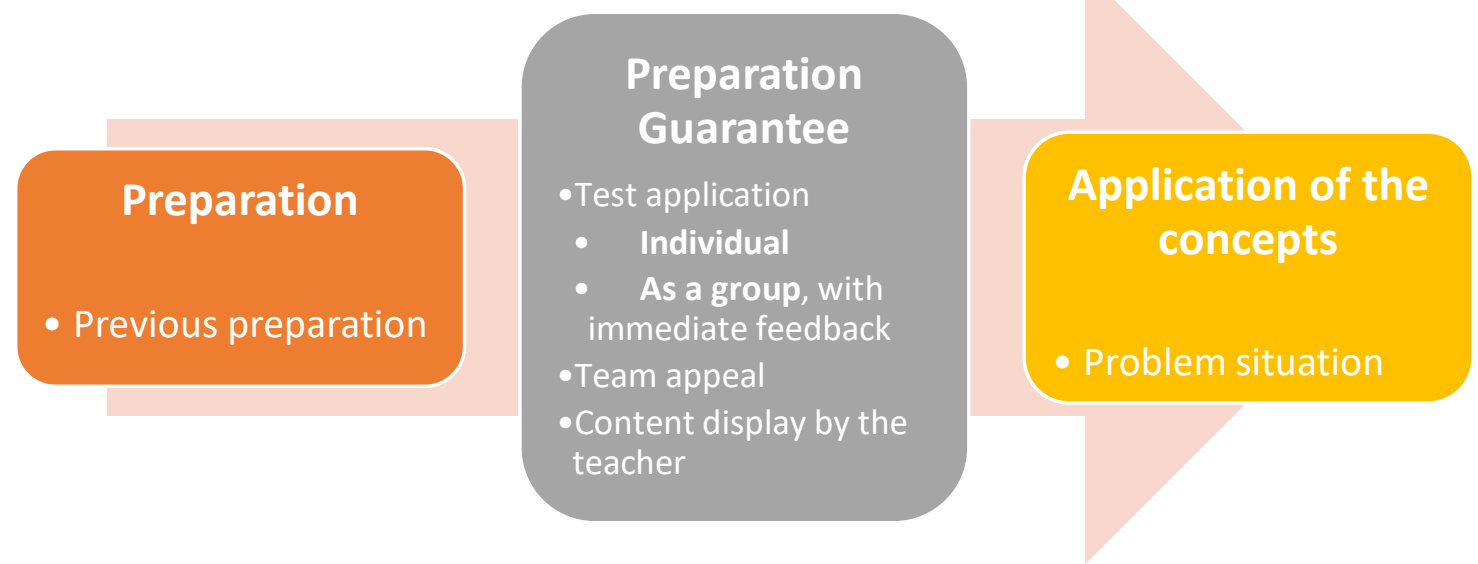

Source: Authors (2020)

The preparation phase is when the methodology begins. It involves planning and organizing the methodology in a way that the student has a first contact with the new content yet to be broight by the teacher. It should act as a ground to the next phases, as Krug et al. (2016, p. 606) state: "the previous preparation of the activity makes the student capable of developing greater maturity and responsibility towards its knowledge. This preparation is going to be checked at the next phase of the cycle, which happens in the classroom". The teacher provides, through written material (printed or through electronic media, videos or other ways that the teacher finds to be pertinent), to the students the capacity of reading about the subject before the class, making them more prepared to participate in the proposed steps.

In the preparation guarantee phase, the level of preparedness of the students in order to participate in the methodology is identified in two different steps: one of them is individual, without any consulting, the other one is in a team. According to Krug et al (2016, p. 604), "the experience is done in the classroom, initially, through an individual test, which is posteriorly done as a team, with feedback and possibility of appeal, along with a brief introduction by the teacher". The preparation guarantee test, along with the individual test, seeks to identify what every student understood from the reading previously the available materials. This quiz must be answered without any consultation. It consists in a multiple-choice quiz with four to five 
options per question. The student may choose between one or more answers which it deems to be correct. Bollela, Helena, Tourinho \& Amaral (2014, p. 295) bring a detailed explanation:

The first step in the process is a guarantee test that evaluates individual preparation (also known as individual readiness assurance tesr - iRAT), which must be answered without any consultation of any bibliographic material. It is consisted of ten to twenty multiplechoice questions that contemplate the most relevant concepts of the previously shown activities.

It is an important step, because it enables the teacher to know if the students have already read the material and in which topics they are struggling. It also indicates how each student is able to contribute to the next step. Besides, from the test application, the teacher can identify if the students are engaging with the proposed activities.

The preparation guarantee test, along with the team test step, induces a moment of discussion about the new content, exchange of information and team interaction. According to Krug et al. (2016, p. 604):

As one of the greatest threats to the development of cohesion among team members is the formation of subgroups based on affinity or personal relationships, is recommended that the students are distributed in groups following a strategic way, that provides a heterogeneous composition.

Following those principles, the teacher is going to form groups in a heterogeneous way, mixing the students in a way to separate them from their usual affinity groups, allowing them to live new experiences. Groups containing five to seven students are formed, depending on the number of students in the classroom. After the formation of the groups, the quiz is applied once again, containing the same questions as the individual test. Nevertheless, at this time, each student has a say in the correct answer, being able to justify its choice, creating a safe space to the other students, so they can proceed in the same way. Regarding this, Bollela et al. (2014, p. 296) state that "the students should discuss the tests, while each member advocates and argues about the reasons for its choice, until the group decides which answer is the best". Thus, during the answers presentation, the team originates discussions while it searches for the correct answer. The feedback regarding the team result is given immediately.

If the team does not concur with the given result, there is time to appeal, in which the team may choose the answer that it finds to be correct. Nonetheless, according to Bollela et al. 
(2014, p. 296), "every appeal should be sustained on arguments, suggestions of improvement and consulting pertinent bibliographical sources". The appeals also must comply to the following steps:

The whole team must write an appeal, along with the references that sustain the argumentation, on a document that may be made specifically for this purpose, which is sent to the teacher. The team also must propose the new format and the correct answer for the question. If the team brings a successful appeal, it earns extra points. The teacher may judge an appeal at the same time of its delivery or at the next meeting. (Bollela, et al., 2014, p. 296)

The teacher is responsible for justifying its answer, in a way that the team is able to comprehend the explanations and that no doubts remain about the subject. After the application of the tests and, if necessary, the judgement of the appeals, the teacher proceeds to explain the content that is going to be seen at the methodology, in a way that it finds adequate. The class may be expository and the use of technological resources is optional. According to Bollela et al (2014, p. 297), "the teacher, seeking to clarify the fundamental concepts, provides feedbacks to every student at the same time". As the quizzes were already answered, the teacher knows which are the most critical points of view that are going to demand extra attention, in order to clarify the students' doubts. Bollela et al. (2014, p. 297) state that "the students must be sure about the fundamental concepts, in a way they are able to apply them to solve complex issues, that are going to be approached at the knowledge application step". In this way, at the end of the content exposure step, the students are expected to be prepared for the next step of the TBL.

At the end of the methodology process, there is a concept application step, in which the teacher proposes a problem situation in order that the students work as teams and apply the concepts learned in class. It may take the form of either a test question or the introduction of a scenario containing a situation that puts the student in the role of a professional, able to solve the introduced issue. This method intends to challenge the student with calculations, comparisons, interpretations, advanced analysis or syntheses.

The activity must be challenging and Krug et al. (2016, p. 607) explain that "this step of problem solving is based on the " $4 \mathrm{~S}$ " principle, which are the initials to Significant, Same, Specific and Simultaneous". It cannot be too technical, since the purpose of the activity is to make the students reflect and solve a specific situation with critical thinking, not by memorizing 
canned responses. All of the groups have to develop and to present an answer at a set period of time, avoiding copies. An alternative that has been chosen as a mediating tool, not just in this teaching process but also in others, is the use of the Digital Technologies of Information and Communication, which seek to communicate with students that were born in the information era.

\subsection{Technology to apply the active methodology tests TBL: the TBL Active app} In order to make the TBL active methodology more motivating, the researcher Ana Paula Ambrósio Zanelato Marques, from Presidente Prudente/SP - Brazil, at the year of 2018, used technological resources to develop an on-line freely accessible platform in order to assist the application of the Team-Based Learning methodology. Prior to the creation of such an application, individual and team assurance tests were performed using scratch cards. However, such scratch cards were subject to fraud because looking at the back of the card, the correct answer could be identified. In addition, before the TBL app, data tabulation was manual, which entailed a greater demand for time for analysis and a difficulty in providing immediate feedback. The TBL app has been projected to apply tests individually or in groups, it also generates reports about the results obtained by the quizzes. The teacher may access the results immediately and track with which contents the students struggled the most. The app was developed for any device with wi-fi connection, such as computers, smartphones and laptops. The Figure 2 illustrates the main page of the referred app: 
Figure 2.

The main page of the TBL Active app.

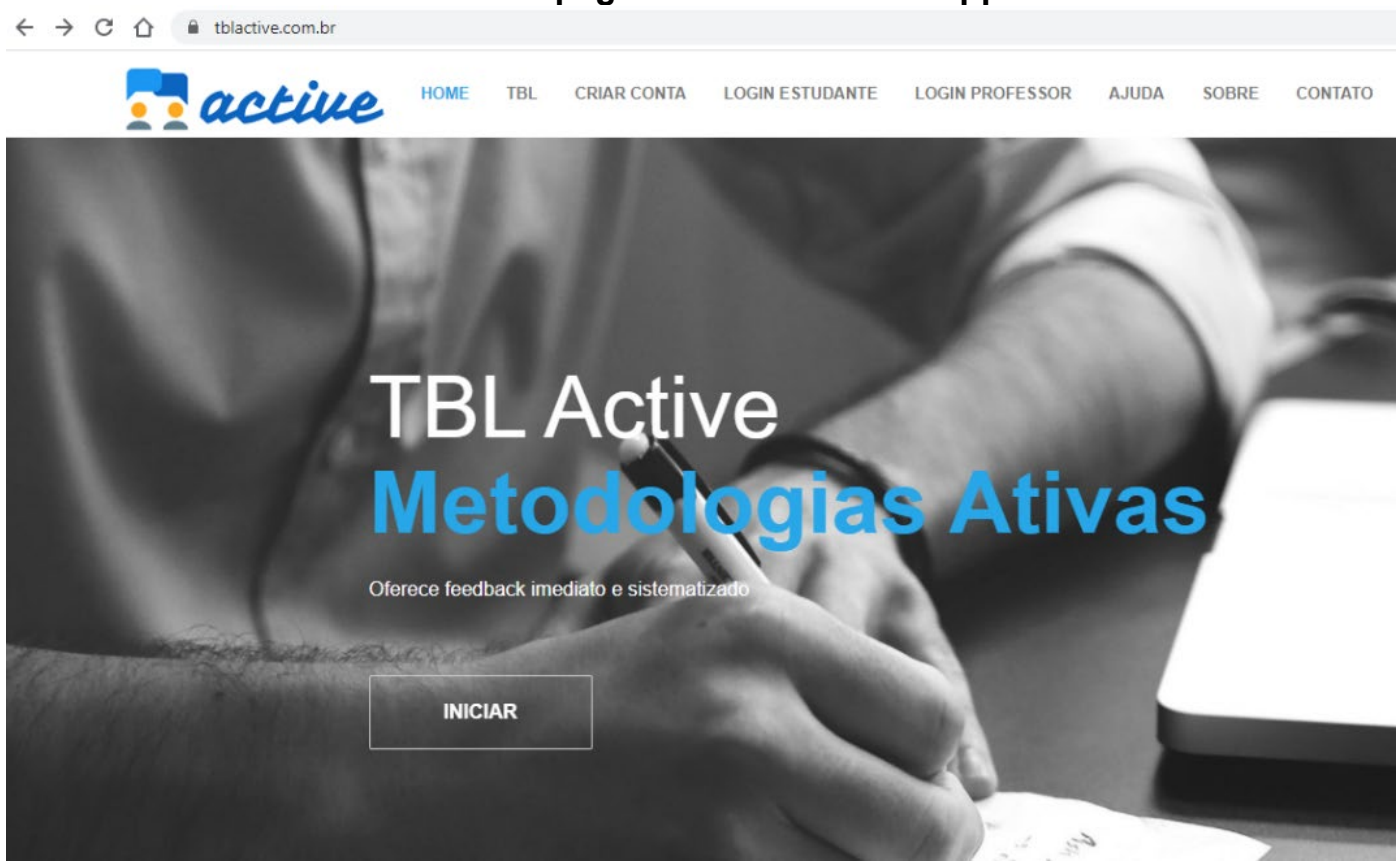

Source: Print screen from the TBL Active software (2020)

The platform may be accessed by the following address: https://www.tblactive.com.brl, the teacher has to create an account, informing and confirming its data. After the teacher is signed up, the following options should appear: My Quizzes, where the registered quizzes are going to be recorded; New Quiz, for the creation of new quizzes and reports, with the students' grades and statistics.

When the New Quiz option is selected, the teacher must inform the name and number of alternatives, then repeating the process for the other questions, always remembering to set the correct answer. After the end of this process, the teacher needs to select "my quizzes" and then the "Play" option, which is going to create a virtual classroom for the test application. The room will be identified with a number, which the students are going to need in order to access the classroom. The teacher must wait until every student is able to enter. In order to do that, the students need to access the TBL Active platform, select "student Login" and input the number of the virtual classroom, as well as its name and academic record. The score system goes according to the teacher's attribution for the right answer. The teacher tracks the students' answers and scores in real time.

After the application of the individual tests, the students take the group test, in which only one member from each group is able to re-enter the classroom, identifying the group's 
members and its name. The members must, then, discuss and inform the alternatives that they believe to be correct. Each incorrect answer lowers the team's score. The teacher keeps up with the answers. The test is finished only when all of the teams have finished the quiz. Then, the teacher accesses the grades' report and identifies the questions with which the students struggled the most.

Even though the methodology does not end right after the application of the quiz, this tool helps the teacher to apply the tests and to identify the major struggles in a short period of time and attractively. After the results, the teacher proceeds with the methodology, proposing an activity that stimulates the student to think critically.

\section{Methodology}

\subsection{Research Approach}

This research is structured in a mixed composition. It is a qualitative research, because it is based on an observation instrument which is used to collect information and apply a point of view towards reality, without neutrality, seeking to comprehend or interpret a phenomenon, without generalizing its discoveries. The data collection was made through quantitative methods, which involve surveys that made possible to obtain numbers and percentages in order to interpret and compare results.

The research has been projected to be applied using an intervention purpose, by the use of the Team-Based Learning methodology, mediated through specific technology from the TBL app. The research took place in the first half of 2019.

\subsection{Context and Participants}

The research was done in a free technical education school located in a small town in the state of São Paulo, in the technical course in administration and focused on the curricular component I.6 - OPERATIONAL ACCOUNTING, which aims at: Planning, Operation and Accounting Process Control. Thirty-four students, were enrolled in the course until the end of the first semester of 2019. The research was registered and approved by the Ethics and Research Committee at Plataforma Brasil, receiving the Certificate of Presentation of Ethical Appreciation: 03824918.0.0000.55150. The teacher, the participants of legal age and the parents of the minor students signed the Free and Informed Consent Form. The Term of Assent was signed by underage students. Table 1 indicates the profile of the students divided by age: 
Table 1.

Students' Profile by age

\begin{tabular}{|lll|l|l|l|l|l|l|l|l|l|l|l|}
\hline Student's age & 15 & 16 & 17 & 18 & 19 & 20 & 23 & 26 & 27 & 34 & 36 & 42 & 43 \\
\hline Number of students & 3 & 7 & 10 & 5 & 1 & 1 & 1 & 1 & 1 & 1 & 1 & 1 & 1 \\
\hline
\end{tabular}

The table above shows that most of the students who were part of this research were between 15 and 20 years old, this portion represents $79,4 \%$ of the classroom. Only four of the students are over 30 years old. The following Table 2 represents data regarding the educational stage in which the students are in:

Table 2.

Students' profile by educational stage

\begin{tabular}{|l|r|r|r|r|}
\hline & Number of students & \multicolumn{3}{c|}{ Number of students } \\
\hline Graduated in high school & YES & \% & NO & \% \\
\hline Graduated in another subject & 19 & 55,88 & 15 & 44,12 \\
\hline
\end{tabular}

Source: Authors (2020)

As for the educational level, 19 students have already graduated in high school and 15 were in the senior year of their respective graduations. Only 8 of the students have graduated in another subject. When questioned about what they intended to do after concluding the technical course, only 7 of the 34 students intended to enroll in a college, 22 of the students had intentions of entering in the labor market and the remaining 5 still didn't know what they wanted to do.

When asked about their use of technology on a daily basis, only one student answered negatively, the other 33 usually made use of mobile devices. Nineteen students usually utilized mobile devices and computers. The students, aware of the research, answered the survey spontaniously and consented to be a part of it. None of the students opposed to the conditions. In fact, all of them proved to be receptive towards every one of the stages in which they were invited to participate.

\subsection{Data Collection Instruments}

Some individual tests (Appendix A) were applied to verify what the student was able to comprehend regarding about accounting content to be worked on after reading the material previously made available. Then, the test was applied to be answered based in the consensus of the groups. The data collection regarding those tests was made by the use of the TBL Active 
software, which produced reports not only about the individual answers, but also about the teamwork results.

By the end of the process, the students were asked to take on-line survey (Appendix B), made with Google Forms. This process intended to verify the perception of each student regarding the learning experience through the use of the teamwork active methodology along with the technology in order to learn the concepts related to the Accounting contents in the technical course in Administration.

Another instrument that was used to collect data was the observation through the TBL process, once "the main advantage of the observation process in relation to other techniques is that the facts are perceived in a direct way, without any intermediation" (Gil, 2008, p. 100).

\subsection{Analyses Procedure}

As the research collected both quantitative and qualitative data, the triangulation method was utilized in order to lead to a more consistent analysis, which seeks to contemplate the rigor of objectivity and subjectivity towards the analysis. The collected data went through a statistical analysis regarding the scores for both tests (individual and group). The Likert scale was applied to the data regarding the tests, making clear the use of the TBL methodology for the process of concept building. The TBL active software ${ }^{5}$, which was built specifically for the active methodology of team-based learning, was used to analyze data. This software already provides a statistical data report.

\section{Results and discussion}

\subsection{Intervention Description}

In partnership with the coordination and the classroom teacher, at April 24, 2019, the TBL methodology was applied for the first time in a public technical education school, in the technical course in Administration, regarding the Operational Accounting Processes curricular component. The material was made by the teacher, who presupposed that all the steps of the TBL application would happen at a single day, once the teacher was responsible for five classes at this same day.

The reading material was available previously via WhatsApp. The students, though, had no obligation to read the content outside of the classroom. The methodology had to be adapted,

\footnotetext{
${ }^{5}$ Available on the site www.tblactive.com.br
} 
because the school had an implicit rule which involve not sending homework to the students, since they usually engage in other activities outside of the school, such as studying and working.

The individua test regarding the Accounting content was applied using the TBL Active software, which is freely accessible through the website www.tblactive.com.br. The system requires the user to create a teacher account in order to access the contents, which can be done by clicking in the Teacher Login option.

When the teacher starts to apply the test, it can trach the students' answers through a screen that is shown in the figure 3 below. The green dots mean that the student answered the question correctly, the red ones are shown when a student selects the wrong answer, the orange dots represent cases in which the student selected more than one answer. However, at that moment, it was not possible to know which answers the students selected and the total score of each student. 


\section{Figure 3.}

Screen representing the tracking of the test results

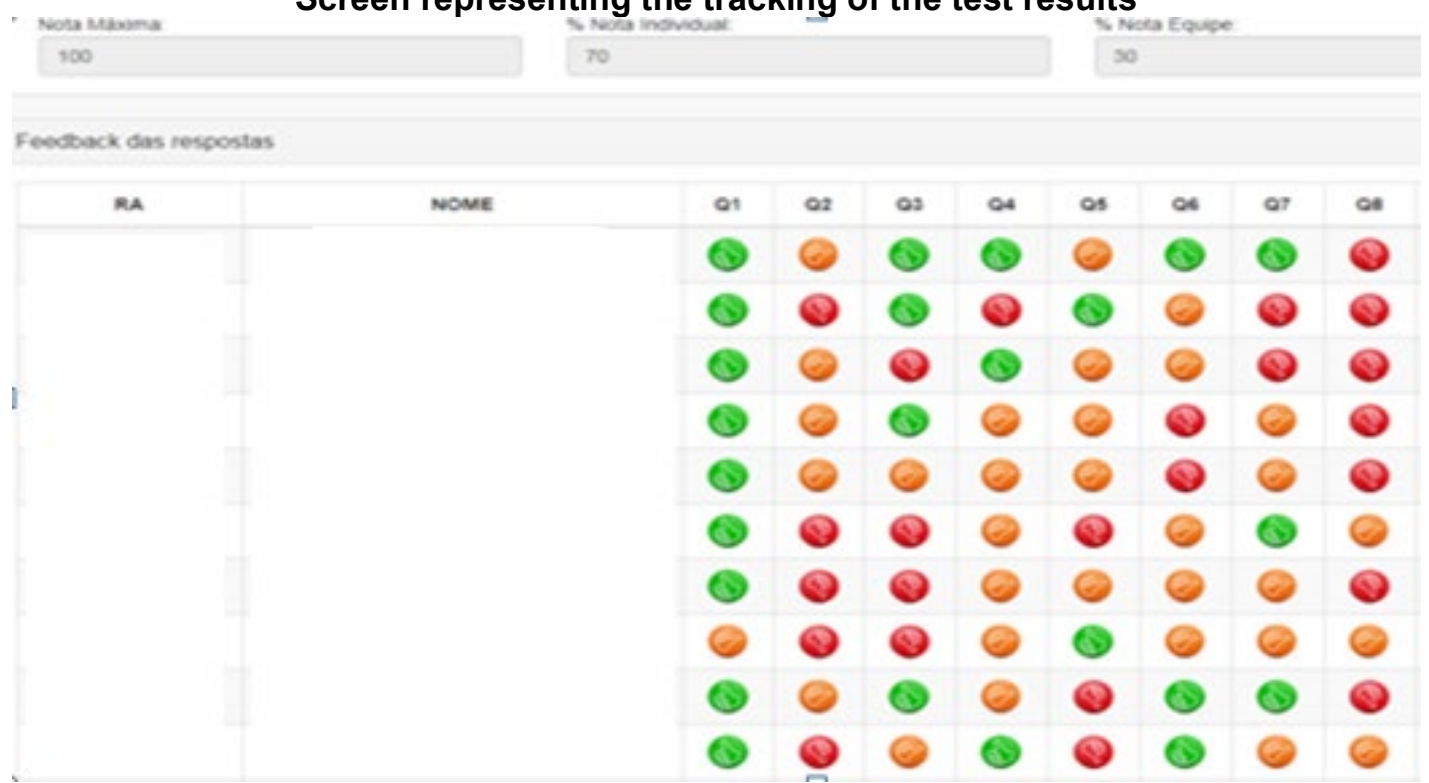

Source: Print Screen from the TBL Active software (2020)

At first, some students complained about the questions being too difficult. However, they kept their commitment and answered the test properly, not showing any signs of disinterest. During the time between the access to the app and the test application, another class has ended. The activities were, then, suspended to a short break.

After that, the teacher set up five groups containing six students and a group containing seven. The teacher could not evenly distribute the groups due to the number of students present at the time. The groups were formed according to the criteria indicated by the methodology, preserving the heterogeneity and avoiding that students would choose groups based on affinity.

It was explained to the students that the test would be applied once again. But, for this time, it would be performed in groups, highlighting the need for every student to participate, in order to enrich the experience. After every student contributed to the discussion, each group had to choose only one answer to each question.

By the end of the group test, the software made possible to analyze two kinds of reports, being one of them regarding the individual performance of each student and the other one about the group test, containing the final score achieved by the students. 
Figure 4.

Management Report - Individual and Group Performance Graph RELATORIO GERENCIAL

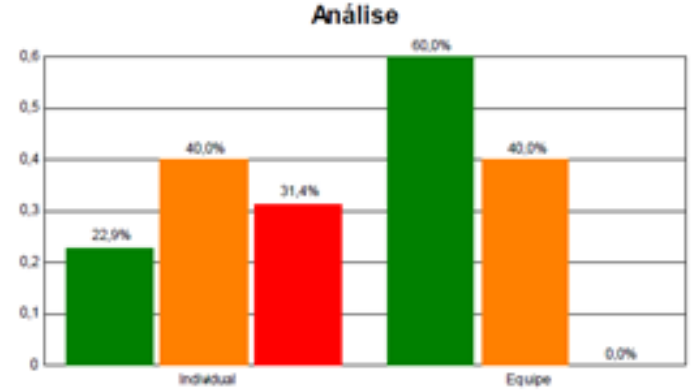

Source: Print Screen from the TBL Active software (2020)

Another report provided by the TBL Active software presents the students' final scores regarding the test. It also contains a sum of both scores: the individual and group one, according to the criteria previously stablished by the teacher.

Table 3.

Final Report with the Test Scores

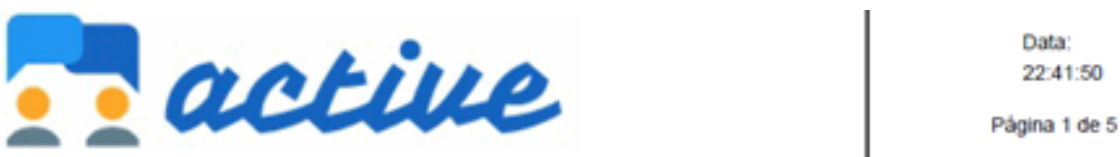

RELATÓRIO FINAL COM PONTUAÇÃO

Questionário: TBL - 1a APLICAÇÃo

Nota Mäxima: 100,00

Periodo de aplicaçāo: 24/04/2019 a 24/04/2019

$\%$ Individual: 70,00

Nota Máxima Individual: 70,00

\% Equipe: 30,00 Nota Máxima Equipe: 30,00

\begin{tabular}{|c|c|c|c|c|c|c|}
\hline$R A$ & Nome & $\begin{array}{l}\text { Qtde Acertos } \\
\text { Individuais }\end{array}$ & $\begin{array}{l}\text { Pontuaçăo } \\
\text { Individual }\end{array}$ & $\begin{array}{c}\text { Qtde Acertos } \\
\text { Equipe }\end{array}$ & $\begin{array}{c}\text { Pontuasçăo } \\
\text { Equipe }\end{array}$ & $\begin{array}{c}\text { Pontuaçăo } \\
\text { Final }\end{array}$ \\
\hline & & 20 & 23,33 & 0 & 0 & 23,33 \\
\hline & & 14 & 16,33 & 43 & 21,50 & 37,83 \\
\hline & & 13 & 15,17 & 41 & 20,50 & 35,67 \\
\hline & & 18 & 21,00 & 41 & 20,50 & 41,50 \\
\hline & & 23 & 26,83 & 43 & 21,50 & 48,33 \\
\hline
\end{tabular}

Source: Print Screen from the TBL Active software (2020) 
The group activity was applied during the last two classes after the break. It was not possible to finish every TBL step in one day. As the next class would happen only in ten days from then, at May 8th, 2019, due to the holiday on May 1st, we decided to let the teacher present the content and clear up the students' doubts during the same class, and then apply the last activity, in which every group was going to solve the same issue and present the result at the same day.

In the next class, on May 8th, 2019, the teacher resumed the content from the subjects with which the students struggled the most in the previous test. The teacher, then, proceeded to revise the general subject. Eventually, the teacher proposed an activity to be done in the same groups used in the last class. The students had to apply the learned concepts in a situation that demanded analysis and reflection in order to be solved. Thus, the Team Based Learning methodology applied through the Tbl active platform developed technical skills such as knowing how to do, or more specifically, the application of accounting contents learned in the stages of individual and team tests in the life of a company. The students were able to solve the problem situation of starting a business, using digital technology to help with accounting management.

By the end of the TBL, some surveys were applied in order to verify the students' perception regarding individual and group learning during the utilized methodology 6 . The survey was created using Google Docs and contained multiple choice questions.

\subsection{Theoretical triangulation: collaborative learning in teams}

The theoretical triangulation made evident that the TBL provided collective team learning, approaching not only the importance of the student's work along with its pairs but also how it affects the learning process. According to Michaelsen (2002, p. 19), "the use of groups, even in a casual way, produces benefits that cannot be achieved when putting students in a passive role". However, the author highlights that the casual groups are not the basis of the methodology, emphasizing that "team-based learning allows the achievement of significative results, which cannot be obtained by the use of temporary groups or occasional group activities" (Michaelsen, 2002, p. 19).

The research worked with a group of students who were enrolled in the Operational Accounting Processes curricular component in the technical course in Administration, with an

\footnotetext{
6 This survey is located at the Appendix A. 
average age between 15-20 years. We noticed that they struggled in comprehending the concepts brought by the teacher. The same struggles could be seen when that the students read previously, in the classroom, the material regarding the TBL methodology. The students also brought up some doubts and complaints about the struggles they were facing to understand what was being asked

When the teams were doing the tests, a lot of doubts came up regarding to the moments in which the students pointed the answers they selected in the individual test and opened to discussions about which could be the right answer.

Recurring to the answers received from the Appendix $B$, some considerations were made using percentages made with Google Docs. At a first glance, we are going to analyze the answers regarding the individual learning.

Table 4.

Adapted Survey About Learning in the TBL Process - Individual Learning

\begin{tabular}{|c|c|c|c|c|c|}
\hline & Fully agree & Partially agree & Indifferent & $\begin{array}{l}\text { Partially } \\
\text { disagree }\end{array}$ & $\begin{array}{l}\text { Fully } \\
\text { disagree }\end{array}$ \\
\hline $\begin{array}{l}\text { I was well prepared } \\
\text { for the activities }\end{array}$ & $33,3 \%$ & $40,7 \%$ & $14,8 \%$ & $11,1 \%$ & 0 \\
\hline $\begin{array}{l}\text { I have contributed } \\
\text { with ideas and } \\
\text { suggestions }\end{array}$ & $48,1 \%$ & $18,5 \%$ & $11,1 \%$ & $18,5 \%$ & $3,7 \%$ \\
\hline $\begin{array}{l}\text { I have helped my } \\
\text { team to elaborate } \\
\text { the answers }\end{array}$ & $63 \%$ & $22,2 \%$ & $7,4 \%$ & $7,4 \%$ & 0 \\
\hline $\begin{array}{l}\text { I have identified my } \\
\text { limitations }\end{array}$ & $48,1 \%$ & $33,3 \%$ & $11,1 \%$ & $3,7 \%$ & $3,7 \%$ \\
\hline $\begin{array}{l}\text { My arguments had a } \\
\text { solid base }\end{array}$ & $44,4 \%$ & $18,5 \%$ & $22,2 \%$ & $11,1 \%$ & $3,7 \%$ \\
\hline $\begin{array}{l}\text { I have respected } \\
\text { diverse opinions }\end{array}$ & $81,5 \%$ & $14,8 \%$ & $3,7 \%$ & 0 & 0 \\
\hline I knew how to listen & $77,8 \%$ & $11,1 \%$ & $3,7 \%$ & 0 & $7,4 \%$ \\
\hline
\end{tabular}

Source: Authors (2020)

The questions referring to the survey above were proposed for the students to evaluate their individual participations in the activity. Michaelsen (2002, p. 18) reinforces that "one of the most important contributions of the team-based learning is the creation of conditions that allow the students to learn about the way they interact with others". The importance of interaction between team members was also highlighted by Oliveira (2014, p. 20) who believes that "[...] diversity benefits advanced students who can enhance their learning by teaching, and 
also help those with difficulty, who learn from their colleagues and add to the discussion among team members".

Analyzing the answers about the individual level of preparedness to perform the activity, they showed to be coherent when self-evaluating themselves. A total of 33,3\% of the students identified themselves as totally prepared, $40,7 \%$ as partially prepared. According to Krug et al. (2016, p. 603) "during its formation, the student should be stimulates to be responsible for acquiring and building knowledge, comprehending how the built knowledge is going to be applied in its future acting".

Another important information refers to the evaluation they made about being capable of identifying their limitations, showing a percentage of $81,4 \%$ of students that believe to have this capacity. Michaelsen (2002, p. 20) believes that "As a result, many learn lessons about themselves, which allow them to be more effective and productive when they graduate school and join the labor market".

Also referring to this survey, when the students were asked about respecting different opinions, a remarkable fact is that $81,5 \%$ of the students have declared to respect diverse opinions. This kind of behavior is important for the success of the teamwork, which should provide reasoned discussions that enrich the debate. Such enrichment, based on interactions, was highlighted by the author Arendes (1995, p. 365), when he stressed that "the organization of small problem-solving groups, consisting of students who sought their own answers, met democratic principles, through of daily interaction with each other". The students need to learn with different points of view, as Krug et al. (2016, p. 603) believe "it must also learn to respect diverse opinions and experiences through a collaboration process along with colleagues from different professions, not only individually, but also in group, seeking the success of the teaching-learning process".

The teamwork strategy seeks long-term results, developing skills and competences so that the knowledge can be built and applied in practice. According to Michaelsen (2002, p. 1), "the effectiveness of team-based learning as an instructional strategy is based on the fact that it promotes growth to the development of high-level group cohesion, which results in a wide variety of other positive results".

Regarding the development and the colleagues' participation in the teams, hereafter, we are going to analyze the obtained percentages about the collaborative learning, which were elaborated from the constant answers for the survey, as shown on the board below:Sí, también con las referencias sobre la política yo no entendía el significado de la dictadura fuera del 
contexto o de mis pensamientos en Estados Unidos. Al principio, yo relacioné lo que estaba pasando con lo que está en Estados Unidos de partidos políticos de derecha e izquierda, pero al final me di cuenta de que la dictadura no es eso (P2. Literatura, Alumna12)

Table 5.

Adapted Survey Regarding the Learning Experience during the TBL Process - Collaborative Learning

\begin{tabular}{|c|c|c|c|c|c|}
\hline & Fully agree & $\begin{array}{l}\text { Partially } \\
\text { agree }\end{array}$ & Indifferent & $\begin{array}{l}\text { Partially } \\
\text { disagree }\end{array}$ & $\begin{array}{l}\text { Fully } \\
\text { disagree }\end{array}$ \\
\hline $\begin{array}{l}\text { Everyone takes part in } \\
\text { the activity }\end{array}$ & $74,1 \%$ & $22,2 \%$ & 0 & $3,7 \%$ & 0 \\
\hline $\begin{array}{lr}\begin{array}{l}\text { There was a good } \\
\text { balance }\end{array} & \begin{array}{r}\text { between } \\
\text { participating } \\
\text { hearing }\end{array} \\
& \text { and }\end{array}$ & $74,1 \%$ & $25,9 \%$ & 0 & 0 & 0 \\
\hline $\begin{array}{l}\text { The questions made } \\
\text { during the discussion } \\
\text { were relevant }\end{array}$ & $77,8 \%$ & $18,5 \%$ & $3,7 \%$ & 0 & 0 \\
\hline $\begin{array}{l}\text { Knowledge has been } \\
\text { shared }\end{array}$ & $81,5 \%$ & $18,5 \%$ & 0 & 0 & 0 \\
\hline
\end{tabular}

Source: Authors (2020).

The participation performance evaluation done by the students is highly important, once it shows the students' perceptions towards responsibility and commitment involving the proposed activity. Krug et al (2016, p. 608) believes that "the evaluation through pairs allows the students to compare their self-evaluations with their colleagues' evaluations". Pointing in the same direction, Michaelsen (2002) states that "the evaluation through pairs is essential, because the team members are usually the only ones with the information needed to evaluate precisely the other person's contribution".

In order to ratify the analysis regarding the students' performances in the teamwork experience, some comments made by the students about their experiences are shown below:

Answering to questions in group helps us to learn better, because we debate different opinions with other people. (student 1).

It was good, helped me to comprehend the subject. Interacting in group was also good, as we shared our knowledge and were able to analyze what we did right and what we did wrong. (student 4).

It was really good, the teamwork method is the best (student 7). 
It did help a lot with the method, we were able to do it by ourselves and then redo it with the group. Thus, we exchanged ideas and knowledge (student 11).

It was a good test. I was able to understand well and, with help from my classmates it became even better. Putting easier words to understand and with less alternative options. (student 15).

Despite not being a class with which I have identified myself and although I have a certain limitation when it comes to understand the subject, I have enjoyed the proposed format. The teachers were always attentive and dedicated to make every student retain the maximum possible knowledge about the given subject (student 20).

In this sense, Michaelsen (2002, p. 17) states that "one of the main goals of team-based learning is to understand and to appreciate the meaning of teamwork regarding the solution of troubling issues - in any aspect of life". He proceeds to say that "one of the most important contributions brought by team-based learning is the fact that it creates conditions that may allow the students to learn about the way they interact with other people" (Michaelsen, 2002, p. 18).

Analyzing the answers to the survey, it is adequate to make a comment about the significant percentage of $81,5 \%$ of the students who fully agreed that there has been knowledge sharing through the TBL process as for the collective learning. The $18,5 \%$ remaining students partially agreed with that statement, leaving no percentages showing disagreement with the other students.

According to the analyzed data, we may conclude that the collaborative team learning is the peak of the methodology, introducing discussion, interaction, knowledge and experience exchanges, reinforcing the debate and the respect for differences.

\section{Conclusions}

The intervention purpose applied to this research was favorable to the analysis of the contributions made by an active methodology, along with a technological tool, to the teaching and learning process in a technical course and in a public school. Among those contributions, it became evident in the results that the teamwork made the collaborative learning possible for all the participants, once it provided a discussion about the concepts and the use of technology in the classroom. With this, the classes were able to join theory to practice with innovation. 
Thus, the applied methodology was well accepted and presented significative results, since it favored an experiential learning of accounting, with an increasing number of correct answers when comparing individual and team answers. Regarding the methodology, it was evident that the differential element was not among the technological resources that assumed the role of mediator tool, as the highlight was in the teamwork, the interaction through pairs and the experience exchanges. The TBL methodological purpose was validated by the teacher, who emphasized the intention to use it in further occasions, seeking for new alternatives for its applicability in the contents concerning the program to be developed. Its articulation with the active software TBL was also successfully validated by both the teacher and the students, since it provides an innovative experience, which can be explained by its ease of access and, specially, because it provides an immediate feedback.

The teachers highlighted that the TBL made the content learning easier, and that the immediate feedback was important, because it showed the students exactly where were their wrongs, making possible to compare with the expected goals for them to reach. The teachers also validated the methodology, pointing that the experience provided an active participation and an active learning of the content.

It is valid to consider that, when applying the methodology for the first time, the scenario was filled with structural difficulties due to a reform that was being carried out in the school building. Nonetheless, it reflects the reality faced by schools that are not yet ready for the use of technology as a mediator tool in education. The teacher sought to overcome those difficulties so that the students could have access to a new methodology, to a different form of building their knowledge and not only receive scientific knowledge in a passive way.

That attitude of overcoming difficulties showed a determined and flexible posture on the part of the teacher. It also became an important lesson, highlighting the need to face and overcome the daily barriers without being discouraged, as well as the need to find alternatives to solve problems, a skill sought by the managers, who need to find quick solutions in order to make decisions. It should be noted that another limitation found during the development of this research is that not all students were involved in the process, partially participating in the debate and arguments about the answers they should choose. Another limitation of the study was the impossibility of comparing the results obtained in the groups with other groups where other strategies could be applied.

In the moment of the second application, the building reform was finished, making the use of a computer laboratory possible, with computers available to the students, with internet 
access. Under those new conditions, no struggles were found in order to develop the methodology, which made possible to follow the prepared steps without any intercurrence.

It was challenging to turn theoretical contents into participative activities, which warns to the need of deeper studies using the active methodologies in formal processes. It is valid to highlight that the use of the active methodology requires a well-structured plan to guide the work, specially when it involves contents that are theoretically dense and filled with technical terms, to which the classroom inversion requires a lot of attention when preparing the material to be shown to the students. Finally, the importance of exploring different strategies that ease the process of classroom inversion is shown once it consists in an essential condition for the success of the methodology.

Lastly, this research brought significative contributions regarding the encouragement of teachers to seek new methodologies, encouraging them to risk and innovate with the use of technological resources as tools in this process, seeking to turn the traditional classroom into moments of active participation for the students. The creation of new possibilities of application seen by the teacher and the satisfaction of the students with the results achieved by them are reasons to encourage educators who are enthusiastic about the search of good results in the learning and teaching process.

\section{Referencias}

Arendes, Richard. (1995). Aprender a ensinar. Lisboa: McGraw.

Berbel, Neusi. (2011). As metodologias ativas e a promoção da autonomia de estudantes. Semina: Ciências Sociais e Humanas, 32(1), 25-40. Retrieved from http://www.uel.br/revistas/uel/index.php/seminasoc/article/view/10326/0

Bollela, Valdes, Helena, Maria, Tourinho, Francis \& Amaral, Eliana. (2014). Aprendizagem baseada em equipes: da teoria à prática. Revista FMRP USP Medicina, 47(3), 293-300. Retrieved from https://www.revistas.usp.br/rmrp/article/view/86618

Chiavenato, Idalberto. (2014). Administração: teoria, processo e prática (5th ed.). Barueri, SP: Manole.

Dewey, John. (1979). Experiência e Educação. Tradução de Anísio Teixeira (3a ed.). São Paulo, SP: Companhia Editora Nacional.

Gil, Antonio Carlos. (2008). Métodos e Técnicas de Pesquisa Social (6ª ed.). São Paulo, SP: Atlas.

Instituto Crescer. (2018). Guia Crescer em Rede: Metodologias Ativas. Edição Especial. São Paulo, SP. 
Krug, Rodrigo, Vieira, Maria, Maciel, Marcus, Erdmann, Thomas, Vieira, Fábio, Koch, Milene, \& Grosseman, Suely. (2016). The "Bê-Á-Bá" of Team-Based Learning. Revista Brasileira de Educação Médica, 40(4), 602-610. Retrieved from: http://www.scielo.br/pdf/rbem/v40n4/1981-5271-rbem-40-4-0602.pdf

Michaelsen, Larry. (2002). Getting Started with Team-Based Learning. Retrieved from https://www.researchgate.net/publication/246322067 Getting Started with Teambased Learning

Oliveira, Carlos Alberto. (2014). Avaliação de proposta estruturada na aprendizagem baseada em equipes (TBL -Team-Based Learning) para utilização em um curso de Medicina (Master tesis). Pontifícia Universidade Católica de São Paulo, São Paulo.

Sakamoto, Sabrina Ramires. (2017). Aprendizagem baseada em equipes: um ensaio clínico randomizado na graduação em enfermagem e a construção de tecnologia educativa (Master tesis). Universidade Estadual Paulista Júlio de Mesquita Filho.

Valente, José Armando. (2014). A Comunicação e a Educação baseada no uso das Tecnologias Digitais de Informação e Comunicação. Revista UNIFESO - Humanas e Sociais, 1(1), 141-166. 1 Retrieved from http://www.revista.unifeso.edu.br/index.php/revistaunifesohumanasesociais/article/view/ $\underline{17}$ 


\section{Appendix A: Accounting test given through the TBL Active software.}

1. Which of the following items indicates the correct functioning of the debit-credit mechanism in the net equity accounts?
a) Raises are registered through debit and decreases are registered through credit;
b) Raises are registered through credit and decreases are registered through debit;
c) Losses are registered through credit and profits are registered through debit;
d) Entries are registered through debit and exits are registered through credit.

2. A debit entry in the furniture and utensils account reflects:
a) A decrease in the liability account;
b) A raise in the liability account;
c) A raise in the assets account;
d) A decrease in the assets account.

3. What can be affirmed When a merchandising is bought in one lump sum?
a) The money is coming from the bank. Therefore, the assets account is being debited;
b) The merchandising counts as an asset. But the assets account value will not change, since the money is coming from the bank;
c) The assets account value raises, because the merchandising stock account is being credited;
d) The liablilty account value raises, because it is debiting through bank in one lump sum.

4. About the rectifier accounts, it is safe to assume:

a) Although the reductor accounts appear in a certain patrimonial group (assets or liability), their balance is contrary;

b) A reductor account in the assets group is creditor by definition. A reductor account in the liability group is debtor by definition;

c) A rectifier account in the assets group has a positive balance and belongs in the liability account;

d) The rectifier accounts reduce the total balance of the group in which they appear. 
5. When buying a vehicle part in cash and part in installments, the accounting entries indicate that:

a) The balance of the vehicle account raises, the bank balace is reduced and the duplicates payments account value raises;

b) The asset account value will raise, because the vehicle account and the bank account are bothe being credited;

c) Both the bank account and the duplicate payments account are debited. The vehicle account is credited;

d) The liability account value raises and the duplicate payments account is debited.

6. The result of an enterprise is generated:
a) The purchase of assets;
b) Through the confront between assets and liability;
c) After the stock control register the merchandising entries and exits;
d) Through the confront between expenditure and revenue. The result varies between profit and loss.

7. Mark the alternative that contains only accounts in the results group.
a) Sales revenue, energy expenditure;
b) Real estate rent, social capital, electric energy;
c) Sales revenue, sales commissions, real estate rent;
d) Aggregate revenue, banks, merchandising stock.

8. Regarding the exercise result count, it is safe to assume:

a) The revenues are debited in counterpart to the transitory results counting account;
b) The result accounts are destined to the net worth so that the balance can be finished.

c) The expenditure is debited in counterpart to the current liabilities.

The revenue also must be finished in counterpart to the cash account or the duplicates receipt account. 
8. Appendix B: Adapted survey ${ }^{7}$ about the learning experience in the TBL process Regarding collaborative learning

\begin{tabular}{|l|l|l|l|l|l|}
\hline & $\begin{array}{l}\text { Fully } \\
\text { agree }\end{array}$ & $\begin{array}{l}\text { Partially } \\
\text { agree }\end{array}$ & Indifferent & $\begin{array}{l}\text { Partially } \\
\text { disagree }\end{array}$ & $\begin{array}{l}\text { Fully } \\
\text { disagree }\end{array}$ \\
\hline $\begin{array}{l}\text { Everyone takes } \\
\text { part in the activity }\end{array}$ & & & & \\
\hline $\begin{array}{l}\text { There was a good } \\
\text { balance between } \\
\text { participating and } \\
\text { hearing questions }\end{array}$ & & & & \\
\hline $\begin{array}{l}\text { The during the } \\
\text { made } \\
\text { discussion were } \\
\text { relevant has }\end{array}$ & & & & \\
\hline $\begin{array}{l}\text { Knowledge } \\
\text { been shared content has }\end{array}$ & & & & \\
\hline $\begin{array}{l}\text { The content } \\
\text { been understood }\end{array}$ & & & & \\
\hline
\end{tabular}

About my learning experience - what have I learned?

\begin{tabular}{|l|l|l|l|l|l|}
\hline $\begin{array}{l}\text { agree } \\
\text { I was well prepared } \\
\text { for the activities }\end{array}$ & $\begin{array}{l}\text { Partially } \\
\text { agree }\end{array}$ & Indifferent & $\begin{array}{l}\text { Partially } \\
\text { disagree }\end{array}$ & $\begin{array}{l}\text { Fully } \\
\text { disagree }\end{array}$ \\
\hline $\begin{array}{l}\text { I have contributed } \\
\text { with ideas and } \\
\text { suggestions }\end{array}$ & & & & \\
\hline $\begin{array}{l}\text { I have helped my } \\
\text { team to elaborate } \\
\text { the answers }\end{array}$ & & & & \\
\hline $\begin{array}{l}\text { I have identified my } \\
\text { limitations }\end{array}$ & & & & \\
\hline $\begin{array}{l}\text { My arguments had } \\
\text { a solid base }\end{array}$ & & & & \\
\hline $\begin{array}{l}\text { I have respected } \\
\text { diverse opinions }\end{array}$ & & & & \\
\hline I knew how to listen & & & & \\
\hline $\begin{array}{l}\text { I have adquired } \\
\text { knowledge while } \\
\text { taking part in the } \\
\text { activity }\end{array}$ & & & & \\
\hline
\end{tabular}

Space for suggestions, comments and criticism:

${ }^{7}$ Adaptado de Sakamoto (2017, p. 25) 
Revista indizada en
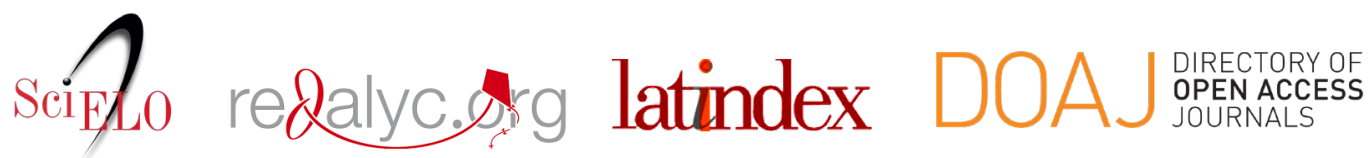

Distribuida en las bases de datos:

- Dialnet

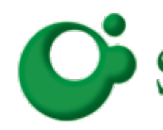
SHERPA/RøMEO

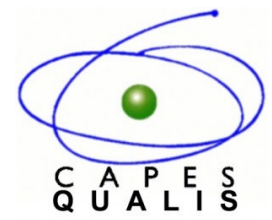

MIAR 